\title{
PENGUKURAN INDEKS KEPUASAN PESERTA DIKLAT TOT WIDYAISWARA DI PUSDIKLAT TENAGA TEKNIS PENDIDIKAN DAN KEAGAMAAN TAHUN 2018
}

\author{
Cut N. Ummu Athiyah \\ Widyaiswara Pusdiklat Tenaga Teknis Pendidikan dan Keagamaan \\ cutathiya@yahoo.com
}

\begin{abstract}
ABSTRAK
Penelitian ini bertujuan untuk mengukur indeks kepuasan masyarakat (IKM) yang diwakili oleh peserta diklat ToT Wisdyaiswara terhadap Pusdiklat Tenaga Teknis Pendidikan dan Keagamaan. Penelitian ini menggunakan data observasi, dokumentasi dan angket dengan skala interval. Jumlah sampel yang digunakan adalah 60 responden. Metode yang digunakan adalah deskriptif kualitatif. Hasil uji reliabilitas instrumen menunjukkan angka 0,905 yang berarti instrumen penelitian reliable atau handal. Hasil penelitian menunjukkan bahwa Indeks Kepuasan Masyarakat, yang terdiri dari 30 indikator dari 14 dimensi layanan menghasilkan persepsi responden rata-rata puas. Indikator-indikator pernyataan yang tidak terpuaskan berada di angka 2,06. Indikator tertinggi dari indeks kepuasan adalah dalam indikator 3,15 dengan rerata 2,75 atau diperoleh dalam kategori baik.
\end{abstract}

Kata Kunci: Tingkat kepuasan, Kualitas pelayanan diklat

\begin{abstract}
This study aims to measure the level of Community Satisfaction Index (CSI) for training participants on the implementation of training and training (ToT) Widyaiswara 2018 in Pusdiklat Tenaga Teknis Pendidikan dan Keagaman. This study uses observation data, documentation and questionnaires with interval scale. The number of samples used is 60 respondents. The method used is descriptive qualitative. Instrument reliability test results show the number of 0.905 which means research instruments is reliable. The results showed that the Satisfaction Index of the Community, consisting of 30 indicators from 14 service dimensions, produced an average perception of respondents satisfied. The indicators of unfulfilled statements are at 2.06. The highest indicator of the satisfaction index is in the indicator 3.15 with a mean of 2.75 or obtained in either category.
\end{abstract}

Keywords:Index, Satisfaction, Service Training 
PENDAHULUAN



publik pada sektor yang oleh aparatur pemerintah saat ini masih banyak dijumpai kelemahan. Kelemahan tersebut tentunya berdampak pada kualitas yang diharapkan masyarakat belum terpenuhi yang ditandai dengan masih adanya pelbagai keluhan masyarakat baik yang disampaikan melalui media massa maupun melalui pelbagai forum lainnya. (Dwiyanto, 2003; Ombudsman Provinsi Maluku,2017). Persoalan tersebut menimbulkan citra yang kurang baik terhadap aparatur pemerintah. Pemerintah perlu terus berupaya meningkatkan kualitas pelayanan mengingat fungsi utama pemerintah adalah melayani masyarakat.

Undang-Undang Republik Indonesia No. 25 tahun 2000 tentang Program Pembangunan Nasional mengatakan bahwa perlu untuk mempersiapkan studi tentang kepuasan masyarakat dan untuk mengembangkan Indeks Kepuasan Masyarakat (CSI) sebagai patokan untuk menilai tingkat kualitas layanan.

Kualitas layanan dapat ditingkatkan melalui elemen/ determinan kualitas layanan. Menurut Lovelock \& Wright (2007), lima elemen ditentukan kualitas layanan adalah: nyata, empati, keandalan, daya tanggap, dan kepastian atau kepastian.
Jenis pelayanan publik pada kementerian atau lembaga memiliki ragam sifat dan karakteristik yang berbeda. Oleh karena itu untuk memudahkan penyusunan Indeks Kepuasan Masyarakat (IKM) unit pelayanan, Kementerian Pendayagunaan Aparatur Negara Reformasi Birokrasi (Kemeneg PAN-RB) menetapkan unsur-unsur penilaian dalam bentuk pedoman umum penyusunan IKM sebagai acuan bagi Instansi sebagai pada Pemerintah Pusat, Pemerintah Provinsi dan Kabupaten/Kota untuk mengetahui tingkat kinerja unit pelayanan di lingkungan instansi masing-masing. Mengingat unit pelayanan mempunyai karakteristik yang berbeda-beda, maka setiap unit pelayanan dimungkinkan untuk menambah unsur yang dianggap relevan.

Kotler (2009) mengemukakan bahwa kepuasan adalah penilaian dari pelanggan untuk penggunaan barang dan jasa dibandingkan dengan ekspektasi sebelumnya penggunaan. Lupiyoadi (2006) berpendapat bahwa masalah kualitas layanan dan kepuasan pelanggan merupakan hal yang penting bagi perusahaan jasa, hal ini mengingat semakin banyaknya produk dan layanan alternatif yang dapat dipilih oleh konsumen dalam memenuhi kebutuhan dan keinginan mereka. Tjiptono, (2009) mendefinisikan kepuasan konsumen sebagai respons emosional terhadap evaluasi pada 
pengalaman konsumsi produk atau layanan.

Wu, dkk (2011) dalam penelitiannya menyimpulkan bahwa kualitas layanan dan citra merek berpengaruh langsung positif terhadap kepuasan pelanggan. Farahmandian, dkk (2013) dalam studinya juga menyimpulkan bahwa siswa puas pada kualitas layanan dan memiliki dampak positif dan signifikan terhadap kepuasan siswa, sementara Arokiasamy, dkk (2012) menyimpulkan bahwa sepuluh konstruksi utama kualitas layanan secara signifikan mempengaruhi kepuasan siswa dalam lembaga pendidikan swasta yang lebih tinggi.

Kualitas pelayanan penyelenggara diklat menjadi faktor yang sangat penting karena kualitas pelayanan yang diberikan akan menentukan capaian para peserta diklat dan mengikuti semua rangkaian kegiatan dalam diklat. Pelayanan oleh penyelenggara diklat ini juga nantinya akan menentukan berhasil atau tidaknya diklat tersebut. Hal ini dapat dimaklumi karena pada dasarnya diklat serta pelayanan yang diberikan merupakan satu kesatuan dari proses yang akan menghasilkan suatu perubahan perilaku sasaran diklat.

Secara konkret perubahan perilaku itu berbentuk peningkatan kemampuan dari sasaran diklat.
Kemampuan ini mencakup kognitif, efektif maupun psikimotor. Apabila dilihatdaripendekatan sistem, maka proses pendidikan dan pelatihan itu terdiri dari input (sasaran diklat) dan output (perubahan perilaku) dan faktor yang mempengaruhi proses tersebut. Dalam teori diklat, faktor yang mempengaruhi proses diklat itu dibedakan menjadi dua, yakni perangkat lunak (software) dan perangkat keras (hardware). Perangkat lunak dalam proses diklat ini mencakup antara lain kurikulum, organisasi diklat, peraturan-peraturan, metode belajar mengajar dan tenaga pengajar atau pelatih itu sendiri. Sedangkan perangkat keras yang juga besar pengaruhnya terhadap proses diklat ialah fasilitas-fasilitas yang mencakup gedung, perpustakaan, alat bantu pendidikan dan sebagainya Soekitjo Notoatmodjo (2003:30).

Penelitian yang dilakukan oleh Chung F. Chiang (2005:2) menunjukkan bahwa ada pengaruh yang signifikan antara kualitas diklat (training quality) terhadap kepuasan diklat (training satisfaction).

Studi lain tentang Indeks Kepuasan Masyarakat (CSI) yang dilakukan oleh Sukamti dan Utomo (2015) menyimpulkan bahwa layanan kesehatan yang disediakan oleh Puskesmas Kalicacing yang diukur dengan indikator indeks kepuasan masyarakat telah dilaksanakan dengan sangat baik. 


\section{Rumusan Penelitian}

Bagaimana nilai Indeks Kepuasan Masyarakat (IKM) pada Diklat ToT Widyaiswara tahun 2018?

\section{Tujuan penelitian}

Untuk mengetahui dan menganalisis Indeks Kepuasan Masyarakat (peserta diklat) terhadap penyelenggaraan diklat ToT Widyaiswara tahun 2018 Pusdiklat Tenaga Teknis Pendidikan dan Keagamaan Kementerian Agama.

\section{METODE PENELITIAN}

Pusdiklat Tenaga Teknis Pendidikan dan Keagamaan sebagai salah satu unit di bawah Kemenag memiliki kewajiban untuk melakukan pengukuran kepuasan pelanggan, dalam hal ini stakeholder dan user diklat teknis pendidikan dan keagamaan, terutama kepuasan peserta diklat yang telah mengikuti diklat di kampus Pusdiklat. Peneliti mengembangkan 30 item dari 14 dimensi berdasarkan prinsip pelayanan sebagaimana telah ditetapkan dalam Keputusan Menteri PAN Nomor: 63/KEP/M. PAN/7/2003. 14 unsur yang "relevan", "valid" dan "reliabel", sebagai unsur minimal yang harus ada untuk dasar pengukuran indeks kepuasan masyarakat adalah sebagai berikut :

1. Prosedur pelayanan, yaitu kemudahan tahapan pelayanan yang diberikan kepadamasyarakat dilihat dari sisi kesederhanaan alur pelayanan;

2. Persyaratan Pelayanan, yaitu persyaratan teknis dan administratif yang diperlukan untuk mendapatkan pelayanan sesuai dengan jenis pelayanannya;

3. Kejelasan petugas pelayanan, yaitu keberadaan dan kepastian petugas yang memberikan pelayanan (nama, jabatan serta kewenangan dan tanggung jawabnya);

4. Kedisiplinan

petugas pelayanan, yaitu kesungguhan petugas dalam memberikan pelayanan terutama terhadap konsistensi waktu kerja sesuai ketentuan yang berlaku;

5. Tanggung jawab petugas pelayanan, yaitu kejelasan wewenang dan tanggung jawab petugas dalam penyelenggaraan dan penyelesaian pelayanan;

6. Kemampuan petugas pelayanan, yaitu tingkat keahlian dan ketrampilan yang dimiliki petugas dalam memberikan/ menyelesaikan pelayanan kepada masyarakat;

7. Kecepatan pelayanan, yaitu target waktu pelayanan dapat diselesaikan dalam waktu yang telah ditentukan oleh unit penyelenggara pelayanan; 
8. Keadilan mendapatkan pelayanan, yaitu pelaksanaan pelayanan dengan tidak membedakan golongan/status masyarakat yang dilayani;

9. Kesopanan dan keramahan petugas, yaitu sikap dan perilaku petugas dalam memberikan pelayanan kepada masyarakat secara sopan dan ramah serta saling menghargai dan menghormati;

10. Kewajaran biaya pelayanan, yaitu keterjangkauan masyarakat terhadap besarnya biaya yang ditetapkan oleh unit pelayanan;

11. Kepastian biaya pelayanan, yaitu kesesuaian antara biaya yang dibayarkan dengan biaya yang telah ditetapkan;

12. Kepastian jadwal pelayanan, yaitu pelaksanaan waktu pelayanan, sesuai dengan ketentuan yang telah ditetapkan

13. Kenyamanan lingkungan, yaitu kondisi sarana dan prasarana pelayanan yang bersih, rapi, dan teratur sehingga dapat memberikan rasa nyaman kepada penerima pelayanan;

14. Keamanan Pelayanan, yaitu terjaminnya tingkat keamanan lingkungan unit penyelenggara pelayanan ataupun sarana yang digunakan, sehingga masyarakat merasa tenang untuk mendapatkan pelayanan terhadap risiko-risiko yang diakibatkan dari pelaksanaan pelayanan.

Tahap selanjutnya, peneliti melakukan uji reliabilitas terhadap 30 indikator dari 14 dimensi, dengan hasil sebagai berikut:

Reliability Statistics

\begin{tabular}{|cc|}
\hline $\begin{array}{c}\text { Cronbach's } \\
\text { Alpha }\end{array}$ & N of Items \\
\hline 0,905 & 30 \\
\hline
\end{tabular}

Berdasar pengujian reliabilitas di atas, diketahui angka cronbach alpha sebesar 0,905 yang berarti lebih besar dari $\mathrm{n}$ minimal cronbach alpha sebesar 0,6 . Oleh karenanya dapat disimpulkan bahwa instrumen penelitian yang digunakan untuk mengukur IKM Pusdiklat Tenaga Teknis Pendidikan dan Keagamaan dapat dikatakan reliable atau handal.

Data penelitian diperoleh melalui kuesioner yang disebarkan kepada peserta diklat. Isi kuesioner adalah indikator-indikator pertanyaan yang mengukur faktor atau dimensi yang diukur dalam skala pengukuran dengan skor 1-4.

Melalui penelitian ini, dilakukan upaya pengukuran kepuasan pelayanan diklat pada ToT Widyaiswara yang berjumlah 8 angkatan pada tahun 2018. Ada 222 peserta yang mengikuti diklat (tabel 1.) Waktu penyebaran kuesioner atau pengambilan data 
adalah tanggal 8 April s.d. 30 Mei 2018 .

\section{Tabel 1. Jumlah Peserta ToT}

\begin{tabular}{|l|l|c|}
\hline No. & \multicolumn{1}{|c|}{ Nama ToT } & $\begin{array}{c}\text { Jumlah } \\
\text { Peserta }\end{array}$ \\
\hline 1. & $\begin{array}{l}\text { Widyaiswara Rumpun } \\
\text { Bahasa Inggris }\end{array}$ & $\begin{array}{c}26 \\
\text { orang }\end{array}$ \\
\hline 2. & $\begin{array}{l}\text { Widyaiswara Rumpun } \\
\text { Biologi dan Kimia }\end{array}$ & $\begin{array}{c}33 \\
\text { orang }\end{array}$ \\
\hline 3. & $\begin{array}{l}\text { Widyaiswara Rumpun } \\
\text { Fisika dan Matematika }\end{array}$ & $\begin{array}{c}34 \\
\text { orang }\end{array}$ \\
\hline 4. & $\begin{array}{l}\text { Widyaiswara Rumpun } \\
\text { Keagamaan }\end{array}$ & $\begin{array}{c}22 \\
\text { orang }\end{array}$ \\
\hline 5. & $\begin{array}{l}\text { Widyaiswara Rumpun } \\
\text { IPS }\end{array}$ & $\begin{array}{c}30 \\
\text { orang }\end{array}$ \\
\hline 6. & $\begin{array}{l}\text { Widyaiswara Rumpun } \\
\text { PAI Angkatan 1 }\end{array}$ & $\begin{array}{c}24 \\
\text { orang }\end{array}$ \\
\hline 7. & $\begin{array}{l}\text { Widyaiswara Rumpun } \\
\text { PAI Angkatan 1 }\end{array}$ & $\begin{array}{c}26 \\
\text { orang }\end{array}$ \\
\hline 8. & $\begin{array}{l}\text { Widyaiswara Rumpun } \\
\text { Bahasa Arab dan Indo- } \\
\text { nesia }\end{array}$ & $\begin{array}{c}27 \\
\text { orang }\end{array}$ \\
\hline $\begin{array}{l}\text { To- } \\
\text { tal }\end{array}$ & \multicolumn{2}{|l|}{$\begin{array}{c}222 \\
\text { orang }\end{array}$} \\
\hline
\end{tabular}

Berdasar jumlah peserta yang mengikuti ToT Widyaiswara, dilakukan pengambilan seluruh jawaban dari penyebaran kuesioner melalui google form. Respon yang masuk yaitu sejumlah 60 orang. Menurut Sekaran (2006:24), desain pengambilan sampel dengan cara probabilitas jika representasi sampel adalah penting dalam rangka generalisasi lebih luas. Bila waktu atau faktor lainnya, dan masalah generalisasi tidak diperlukan, maka cara nonprobability biasanya yang digunakan.

Pada penelitian ini, teknik analisis data dilakukan dengan menggunakan ulasan. Nilai IKM dihitung dengan menggunakan "nilai rata-rata tertimbang" masingmasing unsur pelayanan. Dalam penghitungan indeks kepuasan masyarakat terhadap unsur pelayanan yang dikaji, setiap unsur pelayanan memiliki penimbang yang sama dengan rumus sebagai berikut.

Tabel 2. Nilai Persepsi, Interval IKM, Interval Konversi IKM, Mutu Pelayanan dan Kinerja Unit Pelayanan

\begin{tabular}{|c|c|c|c|c|}
\hline $\begin{array}{c}\text { NLAA } \\
\text { PERSEPS| }\end{array}$ & $\begin{array}{l}\text { NILA INTERVAL } \\
\text { IKMN }\end{array}$ & $\begin{array}{l}\text { NILA INTERVAL } \\
\text { KONERS IKM }\end{array}$ & $\begin{array}{c}\text { MUTU } \\
\text { PELAYANAN }\end{array}$ & $\begin{array}{l}\text { KINERUA UNIT } \\
\text { PELAYANAN }\end{array}$ \\
\hline 1 & $1,00-1,75$ & $25-43,75$ & D & Tidak Bak \\
\hline 2 & $1,76-2,50$ & $43,76-62,50$ & c & Kurang baik \\
\hline 3 & $2,51-3,25$ & $62,51-81,25$ & $B$ & Baik \\
\hline 4 & $3,26-4,00$ & $81,26-100,00$ & A & Sangat baik \\
\hline
\end{tabular}

Bobot nilai rata tertimbang $=$

$$
\frac{\text { Jumlah bobot }}{\text { Jumlah unsur }} \quad \frac{1}{14}=0,33
$$

Untuk memperoleh nilai IKM unit pelayanan digunakan pendekatan nilai rata- rata tertimbang dengan rumus sebagai berikut:

IKM $=\frac{\text { Total dari nilai Persepi per Unsur }}{\text { total unsur yang terisi }} \times \frac{\text { nilai }}{\text { penimbang }}$

Guna memudahkan interpretasi terhadap penilaian IKM yaitu antara 25 - 100 maka hasil penilaian tersebut di atas dikonversikan dengan nilai dasar 
25, dengan rumus sebagai berikut:

Pengolahan data Indeks Kepuasan Masyarakat dapat dilakukan dengan entri data menggunakan aplikasi komputer maupun pengolahan data secara manual.

Untuk pengolahan data secara manual dilakukan dengan langkah sebagai berikut :

- Data Isian kuesioner dari setiap responden dimasukkan ke dalam formulir mulai dari unsur 1 (U1) sampai dengan unsur 30 (U30);

- Langkah selanjutnya untuk mendapatkan nilai rata - rata per unsur pelayanan dan nilai indeks unit pelayanan adalah sebagai berikut:

$>$ Nilai rata-rata per unsur pelayanan.

Nilai masing-masing unsur pelayanan dijumlahkan (ke bawah) sesuai dengan jumlah kuesioner yang diisi oleh responden, kemudian untuk mendapatkan nilai rata-rata per unsur pelayanan, jumlah nilai masing-masing unsur pelayanan dibagi dengan jumlah responden yang mengisi.

Untuk mendapatkan nilai ratarata tertimbang per unsur pelayananjumlah nilai rata-rata per unsur pelayanan dikalikan dengan 0,033 sebagai nilai bobot rata-rata tertimbang.
$>$ Nilai indeks pelayanan.

Untuk mendapatlklan nilai indeks unit pelayanan, dengan cara menjumlahkan 30 unsur dari nilai rata-rata tertimbang.

\section{TEMUAN DAN PEMBAHASAN}

Tabel 3. Prosedur Pelayanan

\section{Prosedur Pelayanan Diklat}

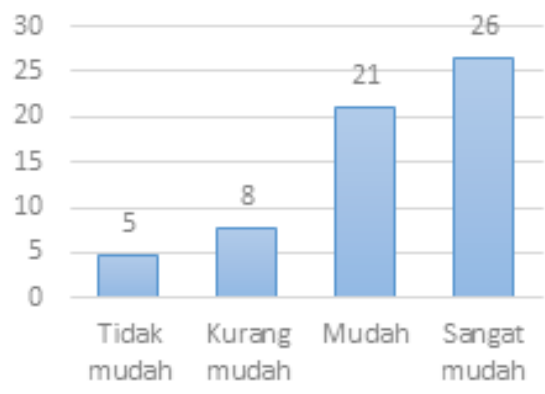

Keterangan: Dari 60 responden, 26 orang menyatakan prosedur pelayanan diklat sangat mudah, 21 orang menyatakan mudah, 8 orang menyatakan kurang mudah, dan 5 orang menyatakan tidak mudah.

Tabel 4. Persyaratan Pelayanan

\section{Persyaratan Pelayanan}

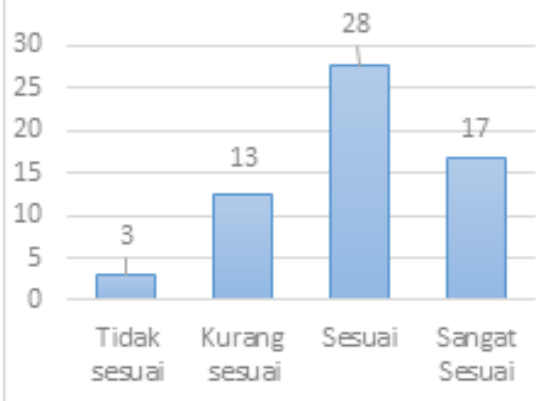


Keterangan: Dari 60 responden, 17 orang menyatakan persyaratan pelayanan diklat sangat sesuai, 28 orang menyatakan sesuai, 13 orang menyatakan kurang sesuai, dan 3 orang menyatakan tidak sesuai

Tabel 5.

Kejelasan Petugas Pelayanan

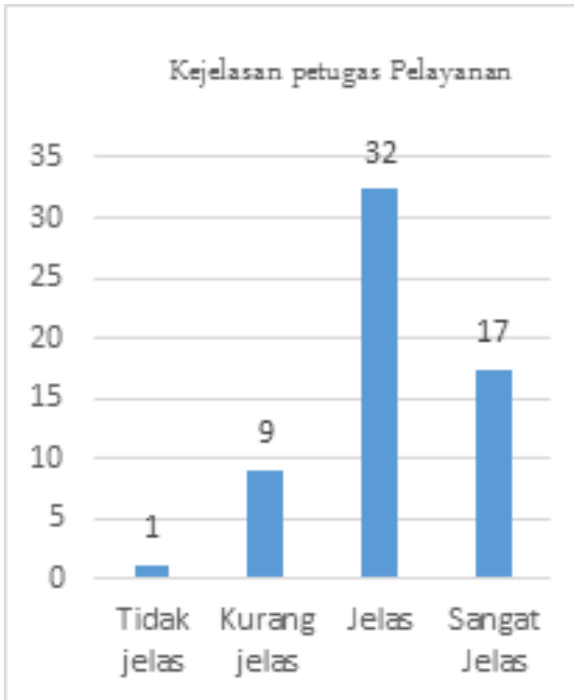

Keterangan: Dari 60 responden, 17 orang menyatakan persyaratan pelayanan diklat sangat jelas, 32 orang menyatakan jelas, 9 orang menyatakan kurang jelas, dan 1 orang menyatakan tidak jelas.

Table 6.

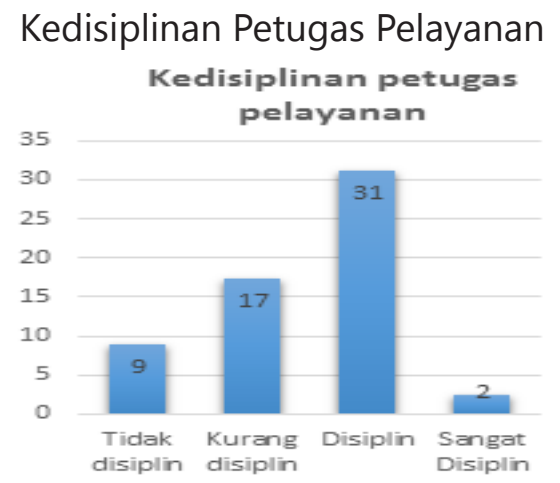

Keterangan: Dari 60 responden, 2 orang menyatakan petugas pelayanan diklat sangat disiplin, 31 orang menyatakan petugas pelayanan diklat disiplin, 17 orang menyatakan petugas pelayanan diklat kurang disiplin, dan 9 orang menyatakan petugas pelayanan diklat tidak disiplin.

Tabel. 7 Tanggungjawab Petugas
Pelayanan

Tanggungjawab Petugas Pelayanan

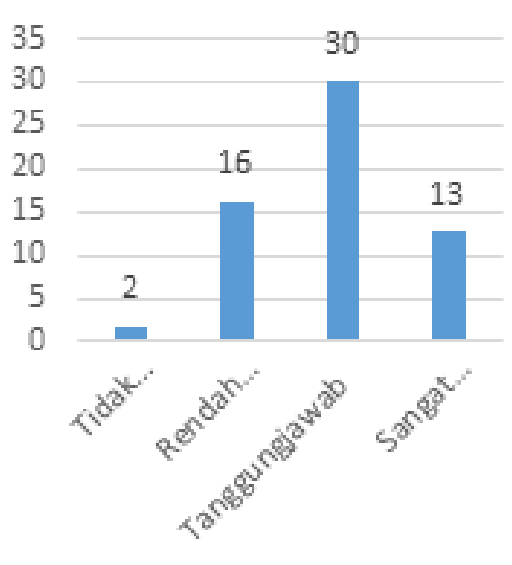

Keterangan: Dari 60 responden, 2 orang menyatakan petugas pelayanan diklat sangat disiplin, 31 orang menyatakan petugas pelayanan diklat disiplin, 17 orang menyatakan petugas pelayanan diklat kurang disiplin, dan 9 orang menyatakan petugas pelayanan diklat tidak disiplin, 
Tabel. 8.

Kemampuan Petugas Pelayan

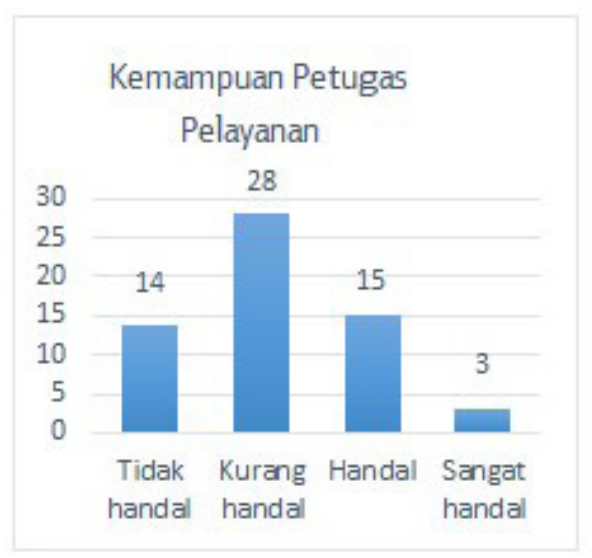

Keterangan: Dari 60 responden, 3 orangg menyatakan kemampuan petugas pelayanan diklat sangat handal, 15 orang menyatakan petugas pelayanan diklat handal, 28 orangg menyatakan petugas pelayanan diklat kurang handal, dan 14 orang menyatakan petugas pelayanan diklat tidak handal,

Tabel. 9. Kecepatan Pelayanan

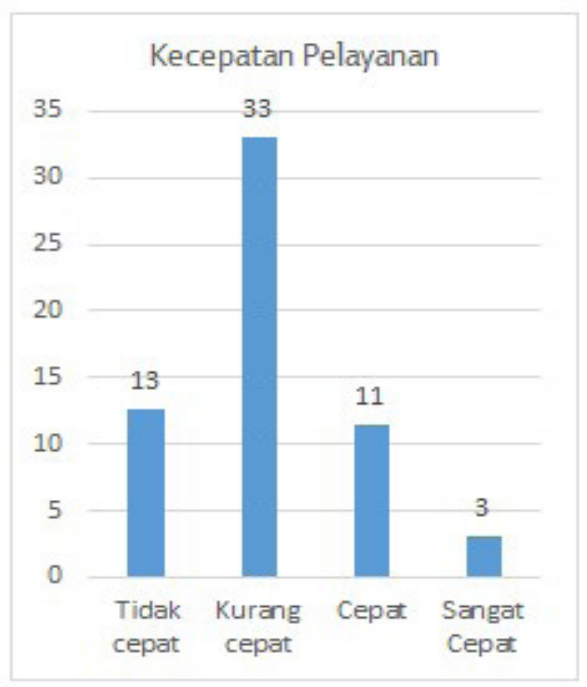

Keterangan: Dari 60 responden, 3 orang menyatakan pelayanan diklat sangat cepat, 11 orang menyatakan pelayanan diklat cepat, 33 orang menyatakan pelayanan diklat kurang cepat, dan 13 orang menyatakan pelayanan diklat tidak cepat.

Tabel. 10.

Keadilan dalam Pelayanan

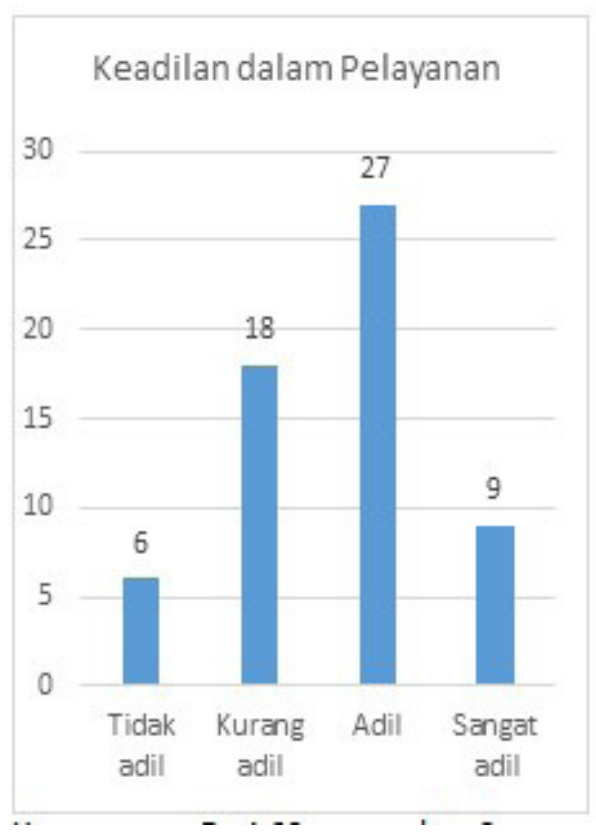

Keterangan: Dari 60 responden, 9 orang menyatakan petugas pelayanan diklat berlaku sangat adil dalam pelayanan, 27 orang menyatakan pelayanan diklat adil, 18 orang menyatakan petugas pelayanan diklat kurang adil, dan 6 orang menyatakan petugas pelayanan diklat tidak adil. 
Tabel 11.

Kesopanan dan Keramahan

Petugas

Kesopanan dan

Keramahan Petugas



Keterangan: Dari 60 responden, 10 orang menyatakan petugas pelayanan diklat berlaku sangat sopan dan sangat ramah dalam pelayanan, 32 orang menyatakan petugas pelayanan diklat berlaku sopan dan ramah, 15 orang menyatakan petugas pelayanan diklat kurang sopan dan ramah, dan 3 orang menyatakan petugas pelayanan diklat tidak sopan dan ramah.

Tabel 12. Kewajaran biaya

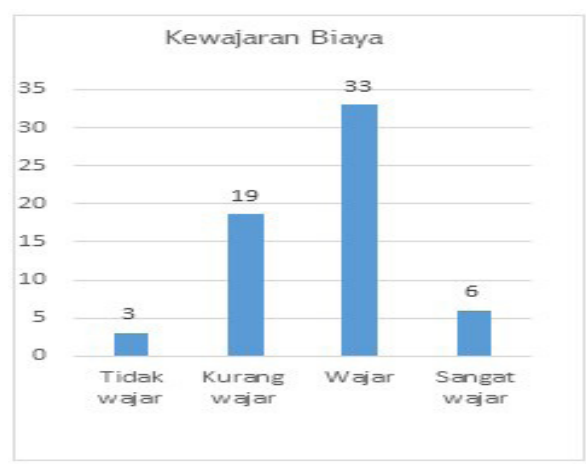

Keterangan: Dari 60 responden, 6 orang menyatakan kewajaran biaya pelaksanaan diklat, 33 orang menyatakan kewajaran biaya pelaksanaan diklat, 19 orang menyatakan biaya diklat kurang wajar, dan 3 orang menyatakan biaya diklat tidak wajar.

Tabel 13. Kepastian biaya

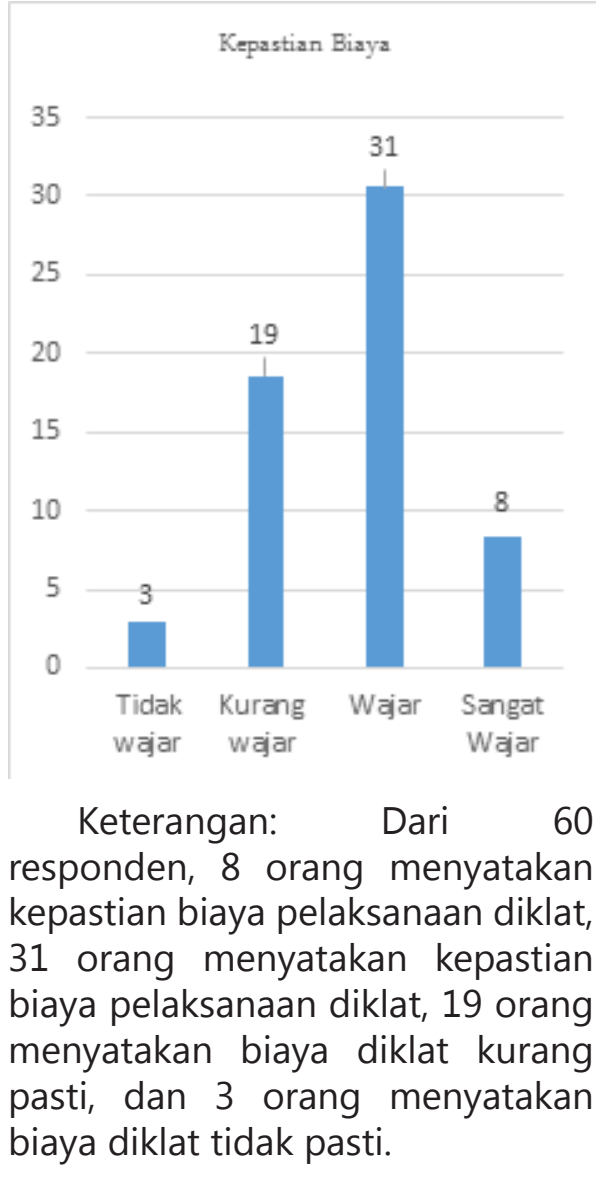


Tabel 14.

Kepastian Jadwal Pelayanan

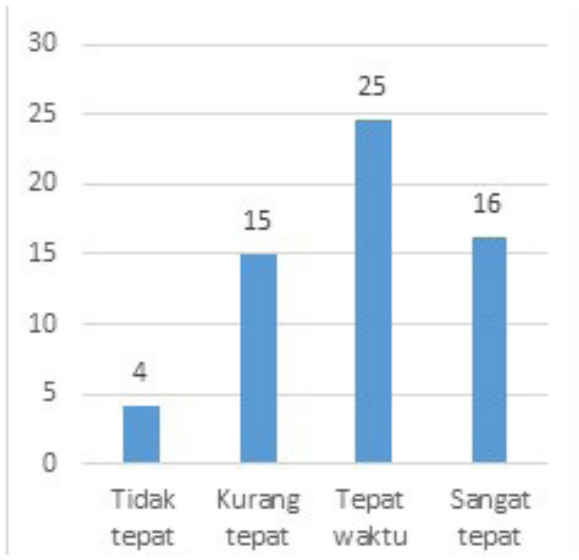

Keterangan: Dari 60 responden, 16 orang menyatakan pelaksanaan diklat sangat tepat waktu, 25 orang menyatakan pelaksanaan diklat tepat waktu, 15 orang menyatakan pelaksanaan diklat kurang tepat waktu dan 4 orang menyatakan pelaksanaan diklat tidak tepat waktu.

Tabel 15. Kenyamanan Lingkungan

\section{Kenyamanan Lingkungan}

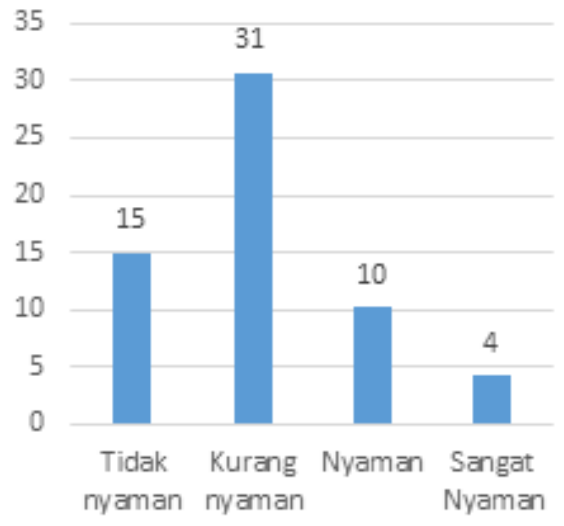

Keterangan: Dari 60 responden, 4 orang menyatakan lingkungan Pusdiklat sangat nyaman, 10 orang menyatakan lingkungan Pusdiklat nyaman, 31 orang menyatakan Lingkungan Pusdiklat kurang nyaman, dan 15 orang menyatakan lingkungan pusdiklat tidak nyaman.

Tabel 16. Keamanan Lingkungan

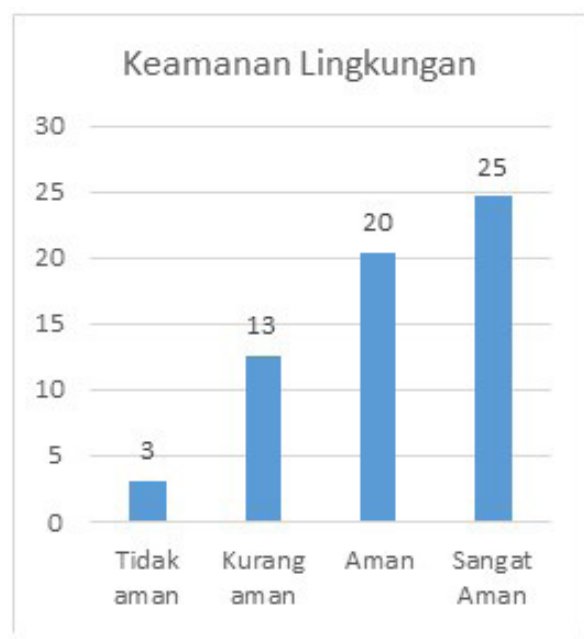

Keterangan: Dari 60 responden, 25 orang menyatakan lingkungan Pusdiklat sangat aman, 20 orang menyatakan aman, 13 orang menyatakan kurang aman, dan 3 orang menyatakan lingkungan pusdiklat tidak aman. 
Tabel 17. NRR IKM Diklat ToT Widyaiswara 2018

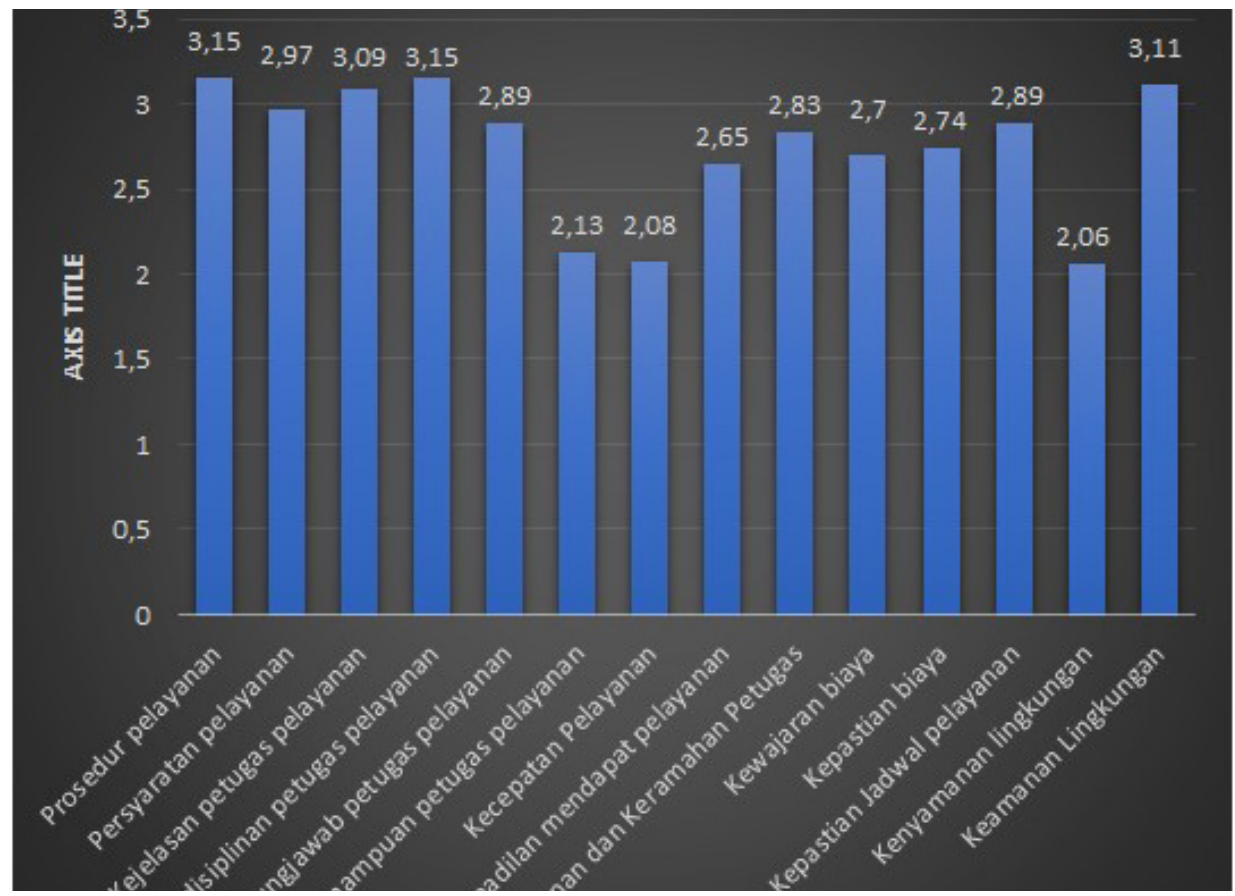

Keterangan tabel 17, sebagai berikut:

1. Prosedur layanan; Nilai NRR 3,15 atau diperoleh kategori mudah. Itu berarti bahwa ratarata responden menemukan prosedur layanan di Pusdiklat Tenaga Teknis Pendidikan dan Keagamaan yang sesuai dengan ketentuan SOP yang ada.

2. Persyaratan layanan; Nilai NRR 2,97 atau diperoleh dalam kategori yang sesuai, itu berarti bahwa rata-rata responden menemukan persyaratan layanan yang sesuai dengan ketentuan yang berlaku.

3. Kejelasan personil layanan;
Nilai NRR 3,09 atau diperoleh dalam kategori yang jelas, artinya rata-rata responden menemukan kejelasan personel layanan dalam memberikan penjelasan dapat dipahami oleh responden.

4. Disiplin personil layanan; Nilai NRR 3,15 atau diperoleh dalam kategori disiplin, itu berarti bahwa rata-rata responden menemukan petugas diklat disiplin dalam melaksankan tugasnya.

5. Tanggung jawab personil layanan; Nilai NRR 2,89 atau diperoleh dalam kategori respon, itu berarti bahwa ratarata responden menemukan 
staf Pusdiklat Tenaga Teknis Pendidikan dan Keagamaan sudah bertanggung jawab dalam menjalankan tugasnya.

6. Kemampuan personel layanan; Nilai NRR 2,13 atau diperoleh dalam kategori kurang mampu, itu berarti bahwa pada responden rata-rata percaya bahwa karyawan mampu dalam melayani.

7. Kecepatan layanan; Nilai NRR 2,08 atau diperoleh kategori cepat, berarti bahwa rata-rata responden percaya bahwa staf kurang cepat dalam melayani peserta diklat.

8. Mendapatkan layanan keadilan, nilai NRR 2,65 atau kategori baik, itu berarti bahwa rata-rata responden percaya bahwa penyelenggaraan diklat ToT Widyaiswara telah adil dalam memberikan layanan kepada pesertanya.

9. Kesopanan dan keramahan staf; Nilai NRR 2,83 atau diperoleh dalam kategori sopan dan ramah, itu berarti bahwa ratarata responden percaya bahwa karyawan sopan dan ramah dalam melayani peserta diklat.

10. Kewajaran biaya layanan; NRR nilai 2,7 atau diperoleh dalam kategori yang wajar, itu berarti bahwa rata-rata responden menemukan biaya layanan didasarkan pada aturan yang wajar.
11. Kepastian biaya layanan; Nilai NRR 2,74 atau diperoleh dalam kategori yang sesuai, itu berarti bahwa rata-rata responden menemukan biaya layanan sesuai dengan ketentuan.

12. Kepastian jadwal pelayanan; Nilai NRR 2,89 atau diperoleh dalam kategori tepat waktu, itu berarti bahwa rata-rata responden percaya bahwa penyelenggara diklat tepat waktu dalam melayani peserta diklat.

13. Kenyamanan lingkungan: nilai NRR 2,06 atau diperoleh dalam kategori kurang nyaman, itu berarti bahwa rata-rata responden menemukan bahwa suasana lingkungan di Pusdiklat Tenaga Teknis Pendidikan dan Keagamaan kurang nyaman.

14. Layanan keamanan; Nilai NRR 3.11 atau diperoleh dalam kategori aman, itu berarti bahwa rata-rata responden menemukan memberikan layanan keamanan kepada peserta diklat.

\section{PENUTUP}

\section{Kesimpulan}

Secara keseluruhan dapat disimpulkan bahwa persepsi responden terhadap kepuasan layanan diklat termasuk kategori puas. Sedangkan pada beberapa indikator terdapat beberapa 
pernyataan dalam kategori kurang puas seperti unsur nomor 6, 7 dan 13. Indikator tertinggi indeks kepuasan adalah indikator prosedur pelayanan dan tingkat kedisiplinan staf yang tinggi yaitu masing-masing 3,15 atau diperoleh dalam kategori baik, namun indeks kepuasan terendah adalah indikator kenyamanan lingkungan Pusdiklat Tenaga Teknis Pendidikan dan Keagamaan dengan NRR 2.06 atau diperoleh dalam kategori yang kurang nyaman.

\section{Saran}

Indeks Kepuasan Masyarakat di Pusdiklat TTPK Kemenag berada dalam kategori baik, namun diperlukan peningkatan layanan diklat.upaya peningkatan mutu berkelanjutan melalui kegiatan penjaminan mutu internal (EDM) maupun eksternal (Akreditasi dan sertifikasi).

Terhadap indikator kepuasan rendah, terutama indikator lingkungan yang kurang nyaman maka perlu ada jaminan, upaya yang lebih serius diperlukan untuk meningkatkan tingkat indeks kepuasan. Upaya bisa dilakukan dengan memindahkan lokasi Pusdiklat ke luar Jabodetabek, atau daerah yang lebih tenang dan jauh dari kemacetan serta kebisisngan.

Meskipun secara keseluruhan penilaian IKM di Pusdiklat TTPK mendapat nilai "BAIK, namun hal ini mencerminkan bahwa indeks kepuasan masyarakat terhadap aspek penilaian tersebut masih belum maksimal karena belum mencapai penilaian "SANGAT BAIK".

Untuk meningkatkan pelayanan pada semua aspek maka manajemen Pusdiklat TTPK diharapkan lebih memperhatikan kekurangannya dalam mengelola diklat di setiap aspeknya, salah satunya adalah dengan mensosialisasikan SOP penyelenggaraan diklat ke seluruh pengelola, membuat persyaratan peserta diklat lebih jelas atau mengikutsertakan pengelola dan pimpinan untuk diklat TOC dan MOT untuk lebih meningkatkan pelayanan. 


\section{DAFTAR PUSTAKA}

Arokiasamy, A. R. A., \& Ghani, A. (2012). Service quality and students' satisfaction at higher learning institutions: A case study of Malaysian University Competitiveness. International Journal of Management and Strategy. (IJMS) 2012, Vol. No.3, Issue 5, July-Dec. 2012.

Chung, F.C., K. B. Joon and D. Deborah, 2005. The Impact Of Employee Training On Job Satisfaction And Intention To Stay In The Hotel Industry. Journal Of Human Resources In Hospitality And Tourism, 4

Dwiyanto, Agus. 2003. Reformasi Pelayanan Publik: Apa yang harus dilakukan?, Policy Brief. Pusat Studi Kependudukan dan Kebijakan UGM.

Kotler\& Keller. 2009 , Marketing management. 13 th Edition, Pearson International Edition

Notoatmodjo, Soekitjo, 2003. Pengembangan Sumber Daya Manusia, Jakarta: Rineka Cipta.

Sukamti, S., \& Utomo, H. 2015 . Analisis indeks kepuasan masyarakat (IKM) pada pelayanan publik di puskesmas Kalicacing Kota Salatiga. Jurnal Among Makarti Vol.8 No.15, Juli 2015.

Uma Sekaran. 2006. Metode Penelitian Bisnis. Jakarta : Salemba Empat

Wu C. C., Liao, S. H., Chen, Y. J., \& Hsu, W. L. 2011 . Service quality, brand image and price fairness impact on the customer satisfaction and loyalty. Proceedings of the IEEE IEEM. 978-1-4577-0739-1/11/\$26.00 (C)2011 IEEE.

Yamin, Sofyan. 2012. Mengukur Tingkat Kepuasan Pelayanan Lembaga Ilmu Pengetahuan Indonesia Dalam Diklat Fungsional Calon Peneliti. Widyariset, Vol. 15 No.1, April 2012

Google. 2005. "Evaluasi Dampak Diklat Second Profesional Human Resources Development Project (PHRDP). Diakses 7 Februari 2016. http://reep.blogspot.com/2005/03/Evaluasi-dampak-diklat-second html 